still under consideration with the Government in the Dutch Indies. It was mentioned, however, that the expedition would probably go to Doreh or to Onin ; many offers to accompany it have been made to the Society.

AT a recent meeting of the Paris Geographical Society, M. Romanet du Caillaud described the life and travels of Ordoñez de Cevallos, who was born at Jaen towards the middle of the sixteenth century, and who commenced his journeys all over the world at the age of seventeen. $\mathrm{He}$ visited various countries in Europe, and travelled several times to both Americas. He then became a priest, without, however, renouncing his dominant passion. He went as missionary to the Philippines, thence to Canton and Japan. From Japan he set sall for China again, but a storm drove him on the coasts of Tonquin. Having received permission to land, he went to the Court in 1590 , and visited various parts of the IndoChinese peninsula, Malacca and India. $\mathrm{He}$ started then for Buenos Ayres, touching at the Cape of Good Hope, and endeavoured to go to the west coast of South America by the Straits of Magellan, but was prevented by an English fleet, which barred the Straits. He returned to Buenos Ayres, and in I595 undertook a journey, similar to that in which Crévaux lost his life, by Tucuman, the Paraguay, Potosi, \&c., preaching by the way to the savage tribes, whom he calls the Quixos, Omaguas, \&c. He fought also agains the black Indian cannibals, called by the Spaniards the Gimarrons or Caribs. Ultimately he returned to Seville and became a canon. In 1607 the Bishop of Macao gave him a message from the King of Tonquin desiring him to return to that country, but he could not do so. The works of this indefatigable traveller are: ( 1 ) "Historia y Viage del Mundo"; (2) "Relaciones verdaderas de los Reynos de la China, Cochinchina, y Champaa" (Jaen, 1628); (3) "Triunfos de la Santissima Cruz"; (4) "Descriptio India Occidentalis," in the "Novus Orbis sive descriptio Indiæ Occidentalis" of Antonio de Herrera (Amsterdam, 1622).

A BLUE-BOOK just issued by the Foreign Office contains five maps referring to the Russo-Afghan boundaries. The first is a chart of the routes followed by members of the Boundary Commission from Kushan to Bala Murghab; the second is a reproduction in English of a Kussian military map of the frontier No. 3 is a copy of a map of South-Western Turcomania, produced in Russia; No. 4, which was prepared by M. Lessar, shows his explorations; while the last is a sketch map to illustrate the various zones and lines of frontier proposed at one time or other recently by Russia and England.

The Austrian Tourist Club has appointed a committee with the view of making experiments for the improvement of the natural drainage of certain parts of the Karst which are liable to periodical inundation. This celebrated region in the north of the Adriatic is remarkable for its underground rivers, which communicate with the surface here and there by vertical shafts. Through these openings the surplus waters escape to the surface when the underground channels are filled to overflowing, and in that way considerable tracts are periodically converted into temporary lakes. The well-known Lake Zirknitz is only one of dozens of such lakes that are formed in this district every year. The practicability of preventing these inundations by enlarging the underground channels has been discussed on several occasions in the Tourist Club, and now the first attempt to carry this scheme into effect is about to be made with the Pinka Jama, a natural shaft leading down to an underground channel about a mile and a half from the Adelsberg Cavern.

HERR GLASER, the Austrian explorer, is about to undertake a new journey in Southern Arabia. He will go first from Sanaa to Marib, and will then visit in succession Wadi-Davassir, Nedjd, Omaun, and Hadramant. In a similar journey which he made some time ago he brought back 276 inscriptions of the Sabeans, who were regarded in the time of the Ptolemys as the wealthiest people of Arabia.

CAPT. JENnings of the Royal Engineers, has returned to India (according to the Pioneer) after a successful exploration of South-eastern Persia, including the hitherto unknown Sarhad country. He carefully examined all the roads and the configuration of the country, and is said to bring back a mass of useful information with regard to this region.

THE last number (xx.) of the Excursions at Reconnaissances of Saigon contains, among others, two papers by that indefatigable student of Indo-China, Capt. Aymonier, one on Cam- bodian epigraphy, the other on a journey in Laos. Dr. Tirant gives the second part of his paper on the reptiles of Cochin China and Cambodia, and M. Hardouin concludes the account of a recent journey in Siam.

Petermann's Mittheilungen (No. 5, I885) contains a paper, accompanied by an excellent map, on Kaffraria and the eastern boundary lands of the Cape Colony, by Herr Schunke, some observations on the sanitary features of the Upper Amu-Darya, and an account of the Geographical Congress at Hamburg.

\section{A YEARLY AND A DAILY PERIOD IN} TELEGRAPHIC PERTURBATIONS

SINCE July I, I88I, all disturbing currents at forty-four telegraphic stations in Norway and Sweden regarding time, duration, force, direction, \&c., have been at my request regularly recorded. These observations will of course first obtain real importance when a longer series is available; still, I believe it would be of interest at present to investigate whether for these telegraphic perturbations a similar yearly and daily period could be established, such as have been proved for the aurora and other terrestrial magnetic phenomena. My time being now rather limited, extensive researches are not possible; of the mentioned forty-four stations I have therefore selected four, and herewith present the results of my investigations.

The four stations are named and located as follows :-

\begin{tabular}{|c|c|c|c|c|c|}
\hline Kistrand $\ldots$ & . & $70 \quad 25 \mathrm{~N}$. & ... & $25 \quad 13$ & E.G \\
\hline Lödingen ... & $\ldots$ & 6824, & $\ldots$ & I6 I & , \\
\hline Trondhjem... & $\ldots$ & 6327 , & $\ldots$ & 8 & \\
\hline Bergen $\quad \ldots$ & ... & 6024, & ... & 520 & \\
\hline
\end{tabular}

My researches have been made for the three years from July, I88I, to June, I884. As the Norwegian stations do not do night work, the observations could only be taken from 7 o'clock in the morning till midnight.

I have first noted the number of days for each month on which telegraphic perturbations have been observed, excluding those caused by thunderstorms. These numbers besider the totals for each month and year are shown in Tables I. to IV.

$$
\text { TABLE I.-Kistrand }
$$

\begin{tabular}{|c|c|c|c|c|c|c|c|c|}
\hline Month & & 8 I to & & 1882 to & & $\mathrm{I} 88_{3}$ to $188_{4}$ & & Total \\
\hline July .. & $\ldots$ & I & $\ldots$ & 2 & $\ldots$ & 8 & & I I \\
\hline August & $\ldots$ & 0 & $\ldots$ & I2 & $\ldots$ & 3 & $\ldots$ & 15 \\
\hline September & $\ldots$ & 7 & $\ldots$ & 12 & $\ldots$ & II & $\ldots$ & 30 \\
\hline October & $\ldots$ & I4 & $\ldots$ & 20 & $\ldots$ & 6 & $\ldots$ & 40 \\
\hline November & $\cdots$ & Io & $\ldots$ & 22 & $\cdots$ & 3 & $\cdots$ & 35 \\
\hline December & $\ldots$ & 13 & $\ldots$ & 8 & $\ldots$ & 3 & $\ldots$ & 24 \\
\hline January & $\ldots$ & 5 & $\cdots$ & 7 & $\ldots$ & o & $\cdots$ & I 2 \\
\hline February & $\ldots$ & 7 & $\ldots$ & Io & $\cdots$ & 9 & $\cdots$ & 26 \\
\hline March... & $\ldots$ & 13 & ... & 16 & $\cdots$ & 4 & $\ldots$ & 33 \\
\hline April ... & $\ldots$ & 25 & $\ldots$ & 6 & $\ldots$ & I2 & $\cdots$ & 43 \\
\hline May $\ldots$ & $\ldots$ & 19 & $\ldots$ & 4 & $\ldots$ & 3 & $\ldots$ & 26 \\
\hline June ... & $\ldots$ & 14 & $\cdots$ & 5 & $\cdots$ & .5 & $\ldots$ & 24 \\
\hline Year & $\ldots$ & I 28 & $\ldots$ & I 24 & $\cdots$ & 67 & $\cdots$ & 319 \\
\hline
\end{tabular}

\begin{tabular}{|c|c|c|c|c|c|c|c|c|}
\hline Month & & I to & & 882 to & & 1883 to & & Total \\
\hline July $\ldots$ & $\ldots$ & 7 & $\ldots$ & 5 & $\ldots$ & 10 & $\ldots$ & 22 \\
\hline August & $\ldots$ & 4 & $\ldots$ & 8 & $\ldots$ & 3 & $\ldots$ & I 5 \\
\hline September & $\ldots$ & IO & $\ldots$ & 6 & ... & 3 & ... & 19 \\
\hline October & $\ldots$ & I5 & $\ldots$ & II & $\ldots$ & 6 & $\ldots$ & $3^{2}$ \\
\hline November & ... & I I & ... & 16 & $\ldots$ & 6 & $\ldots$ & 33 \\
\hline December & $\ldots$ & 14 & $\ldots$ & 6 & $\ldots$ & 5 & $\ldots$ & 25 \\
\hline January & $\ldots$ & 12 & $\ldots$ & 7 & $\ldots$ & I & $\ldots$ & 20 \\
\hline February & $\ldots$ & 16 & $\ldots$ & I0 & $\ldots$ & 4 & $\ldots$ & 30 \\
\hline March... & ... & I 8 & $\ldots$ & 8 & $\cdots$ & 7 & $\ldots$ & 33 \\
\hline April ... & $\ldots$ & I 4 & $\ldots$ & 4 & $\ldots$ & 2 & $\ldots$ & 20 \\
\hline May & $\ldots$ & 17 & $\ldots$ & 2 & $\ldots$ & I & $\ldots$ & 20 \\
\hline June & $\ldots$ & 6 & $\ldots$ & 6 & $\ldots$ & 3 & $\ldots$ & I 5 \\
\hline Year & $\ldots I$ & 144 & $\ldots$ & 89 & $\cdots$ & $5 \mathrm{I}$ & $\ldots$ & 284 \\
\hline
\end{tabular}

The monthly totals for the three years are graphically represented in Fig. I. Both the numbers and the figure show apparently that the yearly period for the telegraphic perturbations is identical with that of the aurora, i.e. its maximum coincides with both solstices and its minimum with both equinoxes. Of especial importance is the minimum at the time of the summer solstice, when the aurora, as is well known, ceases, on account of the 
brightness, of the northern nights. The perspicuity with which the yearly course of the period is drawn in the four representations of Fig. I may even be called surprising, considering the material of observation only embraces three years.

Fig. 1.

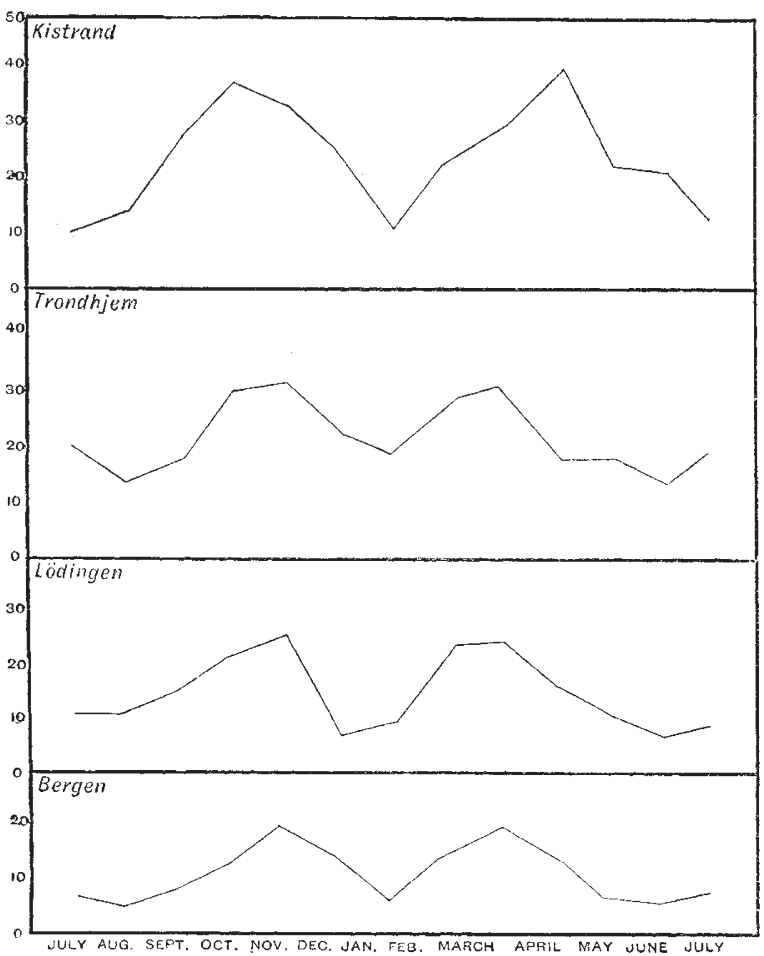

TABLE III.-Lölingin

\begin{tabular}{|c|c|c|c|c|c|c|c|c|}
\hline Month & \multicolumn{3}{|c|}{$188 x$ to 1882} & r882 to & & \multicolumn{2}{|c|}{$x 88_{3}$ to $x 884$} & Tota \\
\hline July $\ldots$ & $\ldots$ & 3 & $\ldots$ & 4 & $\ldots$ & 3 & $\ldots$ & Io \\
\hline August & $\ldots$ & 6 & $\ldots$ & 3 & $\ldots$ & I & $\ldots$ & Io \\
\hline Septembe & r... & 9 & $\ldots$ & 3 & $\ldots$ & 3 & $\ldots$ & 14 \\
\hline October & $\ldots$ & 8 & $\ldots$ & I I & .. & I & $\ldots$ & 20 \\
\hline November & $\ldots$ & 8 & $\ldots$ & 14 & $\ldots$ & 4 & $\ldots$ & 26 \\
\hline December & $\ldots$ & 2 & $\ldots$ & 5 & $\ldots$ & o & $\ldots$ & 7 \\
\hline January & $\ldots$ & 5 & $\ldots$ & 4 & $\ldots$ & 0 & $\ldots$ & 9 \\
\hline February & $\ldots$ & 10 & $\ldots$ & 10 & $\ldots$ & 3 & $\ldots$ & 23 \\
\hline March... & $\ldots$ & 9 & $\ldots$ & 9 & $\ldots$ & 6 & $\ldots$ & 24 \\
\hline A pril .. & $\ldots$ & IO & $\ldots$ & 4 & .. & 3 & $\ldots$ & 17 \\
\hline May ... & $\ldots$ & 7 & $\ldots$ & 3 & $\ldots$ & 2 & $\ldots$ & 12 \\
\hline June ... & $\ldots$ & 2 & $\ldots$ & 6 & $\ldots$ & 0 & .. & 8 \\
\hline Year & $\ldots$ & 79 & $\ldots$ & 75 & $\ldots$ & 26 & $\ldots$ & 180 \\
\hline
\end{tabular}

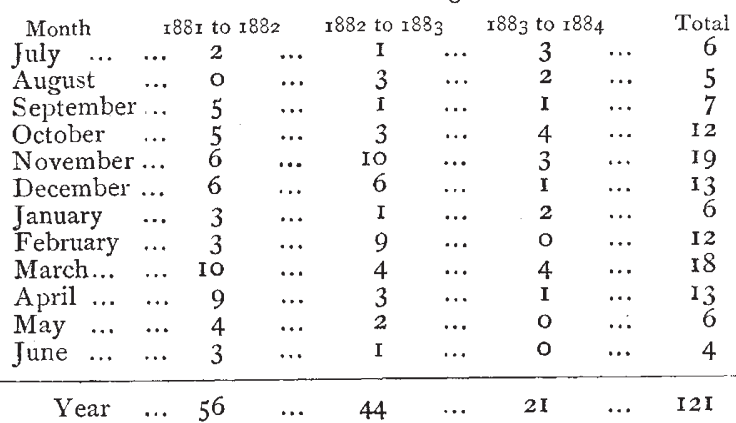

Tables I. to IV. will show the great frequency of these telegraphic perturbations in Norway compared with those of all other countries in Europe. In the totals of the years a constant decrease for all four stations is visible which decidedly coincides with the diminishing appearance of the atirora during recent years in this country. After some years it will probably be seen how the telegraphic perturbations have the II-year period in common with the aurora.

In order to determine the daily period, I have investigated how often during the three years in every hour from $7 \mathrm{a} . \mathrm{m}$. till midnight perturbations have been observed (excluding those caused by thunderstorms). Table $\mathrm{V}$. shows the result :-

$$
\text { TABLE V. }
$$

\begin{tabular}{|c|c|c|c|c|c|c|c|c|c|c|}
\hline & & 7 & 8 & & 9 & & xo & & II & 12 \\
\hline Kistrand & $\cdots$ & 42 & $\ldots 117$ & & 135 & & 139 & $\cdots$ & I4 I & $\ldots \mathrm{r} 37$ \\
\hline Tronihjem & $\cdots$ & 24 & .. $6 !$ & $\ldots$ & 84 & $\ldots$ & 9 I & $\ldots$ & 88 & $\ldots 88$ \\
\hline Lödingen & $\ldots$ & II & 30 & $\ldots$ & 39 & $\ldots$ & 48 & $\ldots$ & 47 & $4 \mathrm{r}$ \\
\hline Bergen ... & $\ldots$ & 9 & 23 & $\ldots$ & 23 & $\ldots$ & 24 & $\ldots$ & 28 & 29 \\
\hline & & I & 2 & & 3 & & 4 & & 5 & 6 \\
\hline Kistrand & $\cdots$ & 122 & $\ldots \quad 128$ & & I 33 & & I 55 & & 177 & I9I \\
\hline Trondhjem & $\ldots$ & $8 \mathrm{I}$ & $\ldots \quad 9$ I & $\ldots$ & 75 & $\cdots$ & 93 & $\ldots$ & 120 & $\ldots 123$ \\
\hline Lüdingen & $\ldots$ & 36 & $4 \mathrm{r}$ & $\ldots$ & 43 & $\ldots$ & 57 & $\ldots$ & 70 & $\ldots 80$ \\
\hline Bergen ... & $\ldots$ & 27 & 43 & $\ldots$ & 37 & $\ldots$ & 40 & $\ldots$ & 42 & 47 \\
\hline ist & & $\stackrel{7}{227}$ & $\begin{array}{c}8 \\
247\end{array}$ & & ${ }_{23}^{9} 8$ & & 10 & & II & 12 \\
\hline ajem & $\ldots$ & I 37 & .. 136 & $\ldots$ & I 38 & $\ldots$ & 77 & & 69 & $6 \mathrm{I}$ \\
\hline ren & $\ldots$ & $9 \mathrm{I}$ & . 96 & & 100 & & 70 & & $6 \mathrm{I}$ & 54 \\
\hline & $\ldots$ & 52 & $6 r$ & & & & $5 \mathrm{I}$ & & $6 \mathrm{r}$ & 59 \\
\hline
\end{tabular}

Fig. 2 gives these numbers in graphic representation. It will

Fig. 2,

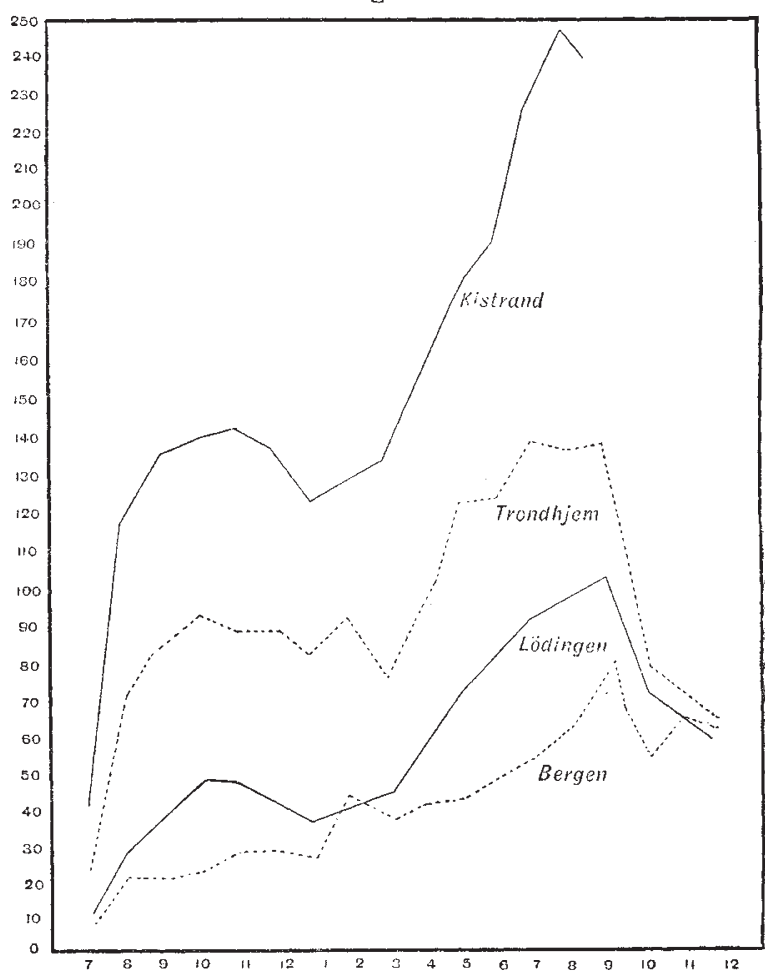

be seen that the telegraphic perturbations show a very prominent maximum in the evening, 8 till 9 o'clock. Intimations of a trifling maximum (with the exception of Bergen) ro till II a.m., and a succeeding minimum $\mathbf{I}$ to 2 p.m. are also visible.

Other occupation taking up my time at present a more extensive and detailed investigation must be postponed.

Christiania

SOPHUS TROMHOLT

A NOTE RELATING TO THE HISTORY OF IHE AUKORA BOREALIS

$A$ MONG northern authors none has given the writers on the Aurora Borealis more to trouble than Peder Claussön Friis, I566-1614, Minister at Undal, near the town of Mandal, in Southern Norway. This, for his time, very productive 